\title{
MANAGEMENT OF STOOL LAND REVENUE IN GHANA: A STUDY OF THE NKAWIE AND TOASE STOOLS OF THE ATWIMA NWABIAGYA DISTRICT OF THE ASHANTI REGION
}

\author{
C.A. Mahama1 and O.A. Baffour ${ }^{2}$ \\ ${ }^{1}$ Department of Land Economy, \\ Kwame Nkrumah University of Science and Technology, Kumasi, Ghana \\ ${ }^{2}$ College of Technology Education, \\ University of Education, Kumasi Campus, Ghana
}

\begin{abstract}
Land plays an important part in the socio-economic development in Ghana. In fact apart from the spiritual dimension of land in the Ghanaian context, it contributes about $60 \%$ of the GDP of the country. Out of the total contribution, the non state sector, made up of individual, family and customary sectors contribute about $80 \%$. Despite constitutional and statutory interventions in the administration of this sector, not much has been achieved in that regard. The management of stool lands, however, has for long time been beset with many problems including indeterminate boundaries of stool lands, poor record keeping which often results in multiple sales and chieftaincy disputes that invariably affect the security of tenure of purchasers and for that matter the productive use of land. Given the constitutional importance of stool lands, this research investigates the impact of stool land revenue in rural areas using Toase and Nkawie Stools of the Atwima Nwabiagya District of the Ashanti Region. To this end, the research assessed the performance of key stakeholders like the Stools, District Assembly and Office of the Administrator of Stool Lands (OASL) Regional Office.
\end{abstract}

Keywords: Stool Lands, Revenue, Management, Toase, Nkawie

\section{INTRODUCTION}

Constitutionally, stool occupants hold land on behalf of and in trust for the entire subjects of the stool. The stool is regarded as an immortal entity and therefore represents the spiritual and physical embodiment of the people. Stool lands are predominant in areas of the country which have a strong centralized political system as exists in most part of the Akan areas in southern Ghana. In these areas, traditional authority is inexplicably linked to land ownership and the stool holds the allodial title in land. In Ghana, eighty percent $(80 \%)$ of land is under customary (non state sector) ownership.

The management of stool lands, however, has for long time been beset with many problems including indeterminate boundaries of stool lands, poor record keeping which often results in multiple sales and chieftaincy disputes that invariably affect the security of tenure of purchasers and for 
that matter the productive use of land. Besides, systematic government intervention since the colonial times has given the state a significant supervisory role in the administration of stool lands even though in principle the stool landowners retain legal and beneficial interest in such lands. Post-independence governments have enacted legislation to vest lands in trust for the benefit of the allodial owners and their communities. For instance, the 1992 Constitution and specific legislation give designated land sector agencies like the Office the Administrator of Stool Lands (OASL) the right to administer stool land revenues and specify how such revenues will be shared between the state, the local government and the allodial owners (Article 267(2) of the 1992 Constitution).

Given the constitutional definition of stool lands, this research investigated the impact of stool land revenue in rural areas using Toase and Nkawie Stools of the Atwima Nwabiagya District of the Ashanti Region. To this end, the research assessed the performance of key stakeholders like the Stools, District Assembly and Office of the Administrator of Stool Lands (OASL) Regional Office.

\section{Land ownership systems in Ghana}

Generally, ownership of land at the local level is under two main classifications; Public and Customary lands. The management of these lands is governed by relevant statutory (constitutional) and customary provisions.

Public lands are vested in the President, on behalf, and in trust for the people of Ghana based on the relevant provisions of the Administration of Lands Act, 1962 (123). Public lands also include other land acquired through the State Lands Act, 1962 (125) or through any other statutes, in the public interest. Public lands are administered by the Lands Commission and its secretariats, as provided in the Lands Commission Act, 1994 (Act 483). They constitute about $20 \%$ of the land mass in Ghana.
Section 36 (8) of the Constitution states: "The State shall recognized that ownership and possession of land carry a social obligation to serve that larger community and, in particular, the State shall recognized that mangers of the public, stool, skin and family lands are fiduciaries charged with the obligation to discharge their functions for the benefit respectively of the people of Ghana, of the stool, skin, or family concerned and are accountable as fiduciaries in this regard"

Generally the following categories of interests are prevalent under the customary land tenure; Stool/ Skin Lands, Family/Clan lands an Individual lands.

\section{Allodial Title}

The customary land holds $78 \%$ of the land with varying land administration systems. The land holders include individual and families, communities, represented by stools, skins and families (Chiefs represent stools and skins which symbolize the community in certain areas).

Depending on locality, the 'allodial' title emanate from discovery, settlement, inheritance, conquest, gift, sale/purchase and or a combination of them. The basic principles underlying customary land law are generally applicable throughout the country.

The salient principles of 'allodial' holding include;

- The 'allodial' title holders are customary trustees only, holding the land on behalf of the whole community;

- A committee of elders, are supposed to help the customary trustees in all aspects of land management including the allocation of land to strangers and the settlement of disputes;

- Land is sacred. Hence obligation is that land should be used judiciously, ensuring that the present and future well-being of the communities are met, and promoted. Positive conserva- 
tion practices include the creation of sacred groves, reservation of old cemeteries, ancestral settlements, headwaters and river courses;

- The customary trustees fully recognize and acknowledge the birth rights and interests held by families and individuals belonging to the land owning group, as well as communal property rights enjoyed by the community at large.

\section{Family Interest and Allodial Title}

Individuals and families from the landholding group hold the 'customary freehold' - denoting the near maximal interest in land. This principle is valid for all parts of Ghana, where the allodial title is vested in the wider community. Chiefs and tendamba belong to families and so have interests in family lands. The interests acquired are secure, alienable and inheritable. Generally, inheritance and succession to property are determined by patrilineal systems in the northern sector, most of the Volta and some Ga communities, and by the matrilineal system in the Akan speaking areas.

\section{Legal and institutional arrangement for man- agement}

The framework for land management in Ghana provides for central government agencies to be responsible for different aspect of land administration. For the sake of this paper, our attention will be focused on only two. These two institutions directly relate to management of stool lands in the country.

\section{The Lands Commission}

The Lands Commission operates under the Lands Commission Act 1994 (Act 483) with the advent of the 1992 Constitution. The Constitution provides for the establishment of a national Lands Commission, along with ten regional Lands Commissions supported by a Lands Commission Secretariat. District Assemblies have representations on the regional Lands Commissions. Article 258 (1) of the 1992 Constitution spells out the functions of the national and regional Lands Commissions as follows. The major ones include:
- To manage all public lands and any lands vested in the president or the Commission on behalf of the government.

- To advise the government, local and traditional authorities on the policy framework for the development of particular areas to ensure that the development of individual pieces of land is coordinated with the relevant development plan for the area concerned.

The Commission is obliged to work within the relevant provisions of the State Lands Regulations, 1962 (LI 230) as well as the Administration of Lands Regulations, 1962 (LI 232) in the discharge of its functions. In all compulsory acquisition cases a permanent site advisory committee advises the commission as to the suitability of the site. The sector Minister is responsible for the allocation of publicly acquired land to ministries, departments or other organs of the Republic, including any statutory corporation, of any land acquired under the Act.

\section{The Administrator of Stool Lands}

The office of the Administrator of Stool Lands was established in 1994 (under Act 481). The administrative functions were formally performed by the Lands Commission. The principal function is the collection and disbursement of all such rents, dues, royalties, revenues or other payments whether in the nature of income or capital and to account for them to the beneficiaries in accordance of the provisions of the constitution;

i) ten percent for the administrator and the remaining to be disbursed in the following manner;

ii) twenty-five percent to the landholding stool through the traditional authority for the maintenance of the stool in keeping with its status;

iii) twenty percent to the traditional authority; and

iv) fifty-five percent to the District Assembly, within the area of authority in which the stool lands are situated. 
Overview of the study area

Atwima Nwabiagya District is one of the largest districts in the Ashanti Region. The district's immediate neighbours in the Ashanti Region are the Kumasi Metropolitan Assembly to the east, Ahafo Ano South and Atwima Mponua Districts to the west, Kwabre and Offinso Districts to the north and Amansie West District to the south. The size of the district is 2,411square kilometer. The major towns include Abuakwa, Barekese, Toase, Akropong, Nerebehi, Sepase, Manhyia, Maakro, Nkawie and Nkawie-Panyin. The district was curved out of the Atwima district in August 2004 by Legislative Instrument (LI) 1738.

Toase and Nkawie are the main focus of this study. Customarily, these two areas are part of the Kumasi Traditional Council. As indicated in the organogram below, the Council is headed by the Asantehene (Otumfuo).The next tier is made up of Paramount Stools followed by Abrenpon and finally Adikro who are chiefs of small towns under the Abrenpon. That is to say, Toase and
Nkawie are Abrenpon and for that matter important players in Asante tradition.

\section{MATERIALS AND METHODS}

This research is based on qualitative and quantitative data collected and compiled in some selected rural and urban communities in the Toase and Nkawie Traditional Areas of the Atwima Nwabiagya District of the Ashanti Region to investigate the impact of stool land revenue in Rural Ghana.

Qualitative data were collected from a sample size of hundred and six (106) stakeholders from twelve (12) communities (Toase and Nkawie inclusive) in the two (2) traditional areas using research tools like snowball sampling, observation, individual and group interviews and focus group discussions. The results were studied and a suitable questionnaire based on the results designed to collect quantitative information from a sample size of two hundred (200) stakeholders who were selected based on purposive sampling. The sample size represents indigenes, strangers and opin-

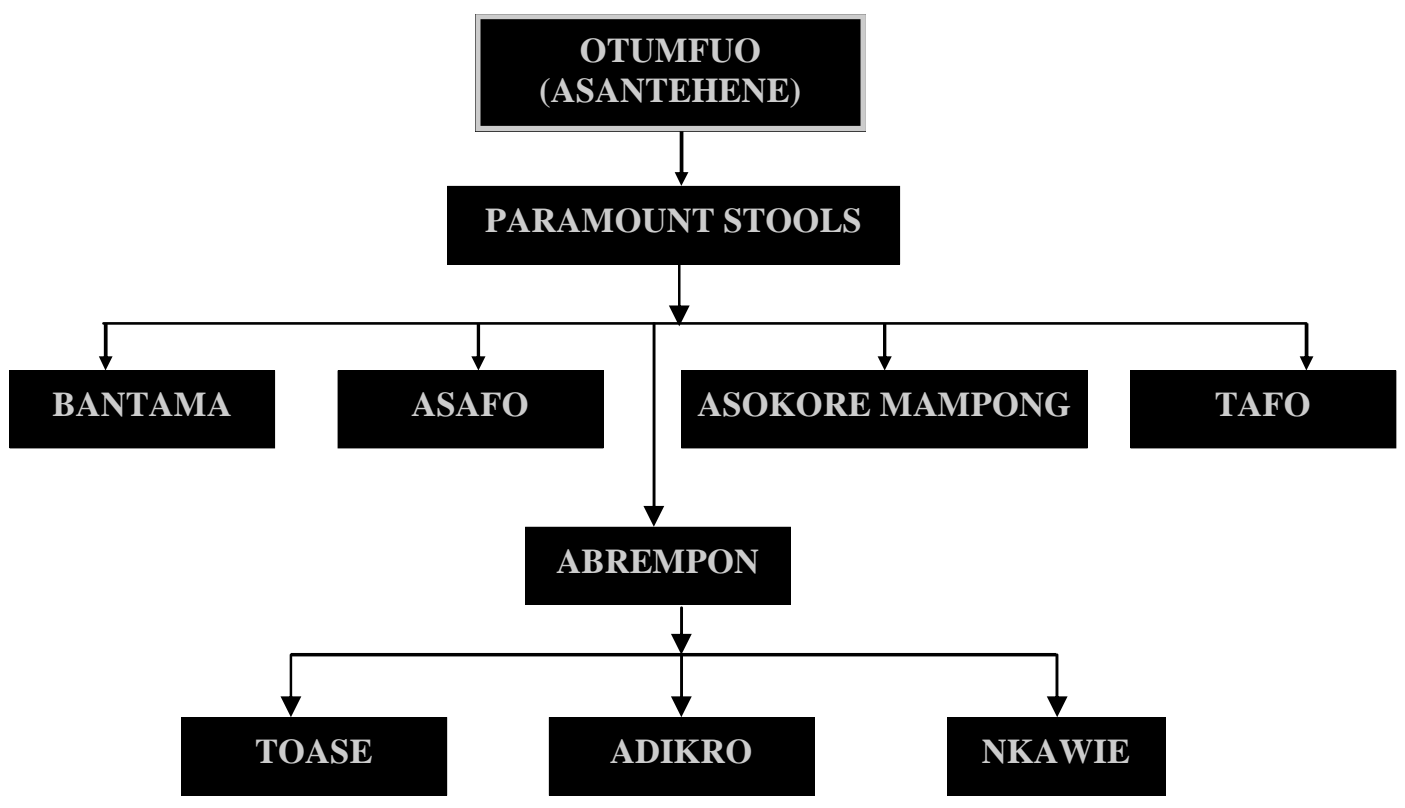

Figure 1: An illustration of the hierarchy of traditional authority in Ashanti 
ion leaders like Assemblymen/women. Besides, the traditional authorities, personnel of the District Assembly and the Office of the Administrator Stool Lands (OASL) were also involved. With respect to data and presentation of results descriptive analysis was adopted because the method best suited the research objectives.

The twelve (12) communities apart from Toase and Nkawie were selected using the snowball sampling because the target communities under the jurisdiction of the Toase and Nkawie Stools were unknown to the researcher. For the qualitative data, purposive sampling was used because certain people in the study area were identified as key informants who possess valid and useful information in respect of the research objectives.

Performance of beneficiaries of stool land revenue in the study areas

As indicated above, the study intended to assess the extent to which stool land revenue is used judiciously in so far as the community is concerned. To that extent, we assessed the recipients of stool land revenue (the Assembly, stools and OASL) based on the projects that they have funded from the revenue received, the level of accountability and public perception about their functions.

\section{The Antwima Nwabiagya District Assembly}

Per Act $462^{1}$, the assembly is the political and planning authority of the area concerned and therefore responsible for its development (see section 10 of Act 462). It does so through different sources of funds; the Social Investment Fund (SIF), District Assembly Common Fund (DACF) and Community-Based Rural Development Project (CBRDP), District development fund and stool land revenue. The Assembly's share of the stool land revenue is the greatest and a main source of income. Its is directed towards the provision of projects that would enhance the living standard of people under its jurisdiction, contrary to criticism that these revenues are used to finance only recurrent expenditure. For instance, the construction of a Circuit Court and District
Police Headquarters at Nkawie at a cost of forty three thousand three hundred Ghana cedis ${ }^{2}$ ( $\mathrm{GH} \phi$ $43,300.00$, about $\$ 4,500$ ) and ninety three thousand Ghana cedis ( $\mathrm{GH} \varnothing 93,000.00$, about $\$ 9,700)$ respectively was partly funded from its share of the stool revenue. Eighty percent $(80 \%)(\mathrm{GH} \phi$ 34,640.00) of the total contract sum of the Court Building and $10 \%(\mathrm{GH} \phi 9,300.00)$ of the Police Station came from its share of the stool land revenue. Additionally, a double cabin Toyota Pickup costing twenty three thousand five hundred Ghana cedis $(\mathrm{GH} \notin 23,500.00$ about $\$ 2,400)$ was purchased out of their share of the stool land revenue to facilitate work at the district office.

Notwithstanding the fact that, the Assembly selects and locates projects based on needs of the various towns and villages under its jurisdiction, it is fair to say here that projects directly funded by stool land revenue have not been proportionately spread throughout the district. This is because all the known stool land revenue projects are sited at Nkawie, the district capital. It therefore follows that indigenes of the endowed natural resource have not adequately benefited from them.

In terms of accountability, the Assembly does not directly account to the Office of the Administrator of Stool Lands (OASL) for use of its share of stool land revenue received annually. However, both internal and external auditors ensure financial prudence at the district. For instance, local government (that is internal) auditors audit financial practices of the Assembly regularly whilst district auditors and "special auditors" from the Auditor General's Office audit the district's finances every six (6) months and two (2) years respectfully. Notwithstanding the above mentioned checks, the Office of the Administrator of Stool Lands as the constitutional organ charged with the collection and disbursement of stool land revenue should also be legally empowered to monitor the use of such revenue.

In the view of the Assembly, the Office of the Administrator of Stool Lands (OASL) has been 
effective in the discharge of its duties. Therefore, the management of stool land revenue should still be handled by the Office. The Assembly contends that, most chiefs may not possess the necessary knowledge and skills to prudently manage stool land revenue. Secondly, the Office of the Administrator of Stool Lands (OASL) acts as an impartial entity in the distribution of stool land revenue to beneficiaries. The Assembly also believes the disbursement formula is "excellent" and should be maintained. This is because the bigger share given to the Assembly means more money for development projects that would benefit the entire people of the district. For instance, the quantum of money received between 1999 and 2005, has served to increase the revenue base of the assembly to pursue more developmental projects.

Table 1: Quantum of Stool Land Revenue Received Between 1999 and 2005 by the Atwima Nwabiagya District Assembly

\begin{tabular}{lr}
\hline Year & Amount $(\mathbf{G H})$ \\
\hline 1999 & $10,320(\$ 10,750)$ \\
2000 & $18,735.8(\$ 19,516)$ \\
2001 & $19,290(\$ 20,930)$ \\
2002 & $39,400(\$ 41,041)$ \\
2003 & $73,700(\$ 76,770)$ \\
2004 & $57,380.1(\$ 59,770)$ \\
2005 & $40,699.7(\$ 42,395)$ \\
\hline
\end{tabular}

Source: Office of the Administrator of Stool Lands Annual Report (2006)

Views of stakeholders on the performance of the District Assembly

Except the occupants of the Toase and Nkawie stools, all stakeholders interviewed indicated their satisfaction with the assembly in respect of the use of stool revenue. The position of the chiefs is not surprising, for they have long criticized the revenue sharing formula as being unfair. Their main concern has to do with the quantum of infrastructure undertaken and the distribution of the facilities across the district. According to them, considering the amount of money received be- tween 1999 and 2006, the assembly should have been able to do more than it claims. However, more than $50 \%$ of the people interviewed praised the Assembly for a good work done so far in relation to the use of stool revenue. The Assemblyman for Toase, for instance said: "I think the Assembly has done well considering the fact that it has so many competing demands from every part of the district that are equally important and that Rome was not built in a day. The Assembly is working to increase its financial capacity and to reach other areas of the district with regard to the use of its share of stool land revenue just as it has done in respect of other revenue sources like the District Assemblies Common Fund'. The Regional Office of the Administrator of Stool Lands, which disburses the funds, commended the assembly as one of the few Assemblies in the region which judiciously uses the revenue for the benefit of people in the area.

\section{The Nkawie stool}

The occupant of the stool, Nana Twum Barima III, recognizes and accepts that, stool land is a communal property. Therefore stool land revenue is supposed to benefit the wider community. The main sources of stool land revenue in the Nkawie area are "drink money", dues, fees, charges from sand winners, charcoal burning and quarterly/ annual payments by Office of the Administrator of Stool Lands (OASL). These payments are ground/farm rents, timber/mineral concessions/ royalties and sometimes compensation.

While acknowledging the important role played by the OASL, the Chief opposes the disbursement formula currently in use. A fairer formula, to him, is thirty-five percent (35\%) allocated to stools whilst the Office of the Administrator of Stool Lands (OASL) maintains its ten percent (10\%) share for administrative purposes, thirty percent (30\%) for the District Assembly and twenty-five percent $(25 \%)$ to the Traditional Councils. The reason for this formula is to allow chiefs to undertake more development projects and to meet the numerous financial challenges confronting them. 
His view is that chiefs can be held more accountable for the use of stool lands revenue than any other institution primarily for two reasons. They hold the land in trust for the community and because of the hierarchical nature of the institution, Asantehene demands regular accountability from his sub chiefs. Within the past years, the stool, with its share of the revenue, constructed two (2) 6 -classroom $\mathrm{JSS}^{4}$ blocks for the community. Besides, ten (10) 2-bedroom bungalows meant for teachers would soon be constructed.

Notwithstanding the fact that accountability for revenues received is made to the Asantehene ${ }^{5}$, the stool could not provide details of how much was disbursed to it from the OASL. However, records from the OASL indicate that over $\mathrm{GH} \notin 42,585$ was disbursed between 1999 and 2006 as Table 2 shows. This brings to fore the need for records keeping data management by the traditional authorities.

\section{Views of stakeholders on the performance of the Nkawie stool}

In recent times the chieftaincy institution is generally perceived to be non-transparent with respect to the use stool land revenue. We sought therefore to assess the use of stool land revenue

Table 2: Quantum of Stool Land Revenue Received by the Nkawie Stool between 1999 and 2006

\begin{tabular}{ll}
\hline Year & Amount $(\mathbf{G H})$ \\
\hline 1999 & $1,023.7(\$ 1,066)$ \\
2000 & $5,752.3(\$ 5,992)$ \\
2001 & $4,786.6(\$ 4,986)$ \\
2002 & $8,969.6(\$ 9,343)$ \\
2003 & $7,897.7(\$ 8,226)$ \\
2004 & $3,666.2(\$ 3,819)$ \\
2005 & $5,372.6(\$ 5,596)$ \\
2006 & $5,116.6(\$ 5,329)$ \\
\hline
\end{tabular}

Source: Office of the Administrator of Stool Lands Annual Report (2006) from the perspective of stakeholders particularly communities under the jurisdiction of the Stool. Towards this end, twenty five people from five of the communities were interviewed. These communities are Ntomoroso, Bayrebon, Abofrem, Tanodumasi and Anansu. The responses were mixed. Outside Nkawie, four $(80 \%)$ out of every five people interviewed in each community or town were not pleased with the performance of the Nkawie Stool with respect to the use of stool revenue. The Odikro of Abofrem, for example, stated without mincing words that laws should be put in place to compel stools to spend at least $50 \%$ of such revenue in their communities. However, the perception of people at Nkawie contrasted that of the communities. More than twothirds $(69 \%)$ interviewed said the occupant of the stool had done a good job especially for investing in educational facilities. This diversity of opinions could be attributed to the disparity in the distribution of facilities among the various communities.

\section{The Toase stool}

The Toase Stool is occupied by Nana Asiama Poku Afrifa Ababio. Like the Nkawie Chief, the occupant of the Toase stool also acknowledges the fiduciary position of chiefs and therefore has a social responsibility towards his subjects. The main sources of stool land revenue in the Nkawie area are "drink money", dues, fees, charges from sand winners, charcoal burning and quarterly/ annual payments by Office of the Administrator of Stool Lands (OASL). These payments are ground/farm rents, timber/mineral concessions/ royalties and sometimes compensation.

Again, like his counterpart, the chief strongly supports the Office of the Administrator of Stool Lands (OASL) in the collection and disbursement of stool land revenue but opposes the disbursement formula. As custodians of stool lands, the Toase chief thinks their share should be increased by $10 \%$ to thirty-five percent $(35 \%)$ with the District Assembly's share reduced by the same margin. 
Part of the proceeds from the OASL has been used to establish an educational fund for the area. Asantehene has over sight responsibility for the use of such moneys. Records management is poor and that may account for the inability of the stool to disclose the exact quantum of stool land revenue received quarterly/annually from the Office of the Administrator of Stool Lands (OASL).

Comparatively, the annual revenue received by the Toase Stool, as against the Nkawie stool, is smaller.

\section{Views of stakeholders on the performance of} the Toase stool

The communities in the Toase traditional areas that were visited to solicit views on the performance of the Toase stool are Betinko, Mpasatia, Anyinansu, Serebuoso and Kwanfinfin. Unlike

Table 3: Quantum of Stool Land Revenue Received by the Toase Stool between 1999 and 2006

\begin{tabular}{cr}
\hline Year & \multicolumn{1}{c}{ Amount $(\mathbf{G H \boldsymbol { c }})$} \\
\hline 2000 & $108.93(\$ 113)$ \\
2001 & $919.57(\$ 1,078)$ \\
2002 & $614.43(\$ 640)$ \\
2003 & $880.54(\$ 917)$ \\
2004 & $3,548.33(\$ 3,696)$ \\
2005 & $3,082.73(\$ 3,211)$ \\
2006 & $1,727.52(\$ 1,799)$ \\
\hline
\end{tabular}

Source: Office of the Administrator of Stool Lands Annual Report (2006)

the communities under the Nkawie chief, the communities under the jurisdiction of the Toase chief were impressed about the performance of the chief in the utilization of the stool's share of stool land revenue. For example, Kwaku Manu who is a farmer at Betinko intimated that as a result of the educational fund set up by the Toase chief some students from the town have been able to complete Senior High School including his daughter.
Office of the administrator of stool lands (OALS) - Ashanti region

The Regional Office has successfully mobilized and disbursed stool land revenue over the years and constitutionally reports to parliament yearly on their performance. The overall performance in terms of Internally Generated Revenue (IGF) collected is illustrated in Table 4.

Table 4: Annual Revenue Performances (IGF) of OALS: 2002-2006

\begin{tabular}{cc}
\hline Year & Total IGF Collected (Amount) \\
\hline 2002 & $179,406.55(\$ 186,881)$ \\
2003 & $160,757.64(\$ 167,455)$ \\
2004 & $227,346.44(\$ 236,819)$ \\
2005 & $239,527.76(\$ 249,508)$ \\
2006 & $380,809.15(\$ 396,676)$ \\
\hline
\end{tabular}

Source: Office of the Administrator of Stool Lands Annual Report (2006)

From Table 4, one realizes that in year 2003 the total revenue collected decreased as compared to the year 2002. However, the total revenue collected in 2004 and 2005 was an increase over the previous years. Even though the rate of increase between 2004 and 2005 is slight (i.e. five percent $5 \%$ ) it is still significant. The 2006 figure is fiftynine percent $(59 \%)$ higher than the previous year. This is considerable and reflects efficiency on the part of the Regional Office.

Secondly, traditional authorities, tenant farmers, mining companies, lessees of stool lands have found the services of the Office useful and therefore almost always utilize their service to improve their operations. Statement of accounts is periodically distributed to beneficiaries to ensure transparency. As indicated above some developmental projects have been provided from stool land revenue mobilized by the Regional Office (OASL) in the land owning communities for the benefit of the communities. The Regional Office has also collaborated with the Land Administration Project (LAP) to establish or strengthen existing cus- 
tomary land secretariats as a way of decentralizing land management services. Examples include Manhyia Land Secretariat and Toase.

Apart from its traditional functions spelt out in the preceding section, the Office has been successful in reducing litigation as result of land disputes through the alternate dispute resolution (ADR) mechanism in Nyinahin stool area between Amansie central and west, Adansi north and Obuasi concerning the sharing of mineral royalties. It has also facilitated the demarcation of farm lands in the new Edubiase area and supervised the signing of farm agreements between stools and settler farmers. Presently, the Office has an outreach team that specializes in public education to improve revenue mobilization and judicious utilization of revenue disbursed to beneficiaries. This is in line with the constitutional and legislative mandate of the Office.

Notwithstanding these achievements, the regional office is beset with a number of challenges which need to be addressed if it is to fulfill its constitutional and legislative functions. The OASL has not been effective in the area of prosecuting defaulters and monitoring of the use of stool land revenue by beneficiaries. This has been the result of weakness in its constitutional mandate due to lack of a Legislative Instrument to facilitate its operations. Secondly, it has inadequate logistical support for field operations - motorbikes, bicycles, vehicles, Lap top computers and so on. This poses a serious challenge to revenue mobilization. Furthermore, inadequate professional staff also serves as a major problem to the Office in its quest to meet its core business. For instance, out of a regional staff of fifty-five (55), only six (6) (11\%) are professionals to man the various districts. These are degree holders in Land Economy or HND holders in Estate Management. Additionally, inadequate office space coupled with "location imbalance" of the existing office space makes effective communication difficult. For example some of the offices of the Regional Office are located on the ground floor whilst the rest are sited on the upper floors of the same block.
Besides, the collection of revenue without adequate information on land users in the study area as a result of lack of clearly marked boundaries makes it cumbersome given the staff situation of the Office. Finally, inadequate and delay in the payment of government subvention due the Office is a problem of the Regional Office of the OASL.

\section{RECOMMENDATIONS}

\section{Records Management}

The management of information relating to land transactions by the stools is nothing to write home about. Therefore, it is suggested that the chiefs should be persuaded to first establish Land Secretariats with Administrative Assistants to professionally manage them. Occasionally the services of professionals like Valuers, Lawyers could be employed to advise the chiefs on matters connected to land administration. Towards this end, the component of the Land Administration Project that would provide support to the stool land administration system to enable the system function effectively and efficiently through the establishment of customary land secretariats is commendable.

\section{"Drink Money" and Accountability}

"Drink money" is no more a token meant to show loyalty or allegiance to a stool for land acquired for developmental purposes. It is now a huge source of revenue to stools or customary landholders. In this regard, steps must be taken by the OASL to rope in "drink money" as one of the principal revenue sources of stool lands. This would call for an amendment of the OASL Law (Act 481). Alternatively, considering the sensitive nature of the matter, mechanisms should be put in place to subject 'Drink Money" to tax.

The revenue from sales and rental of community lands appear to be generally inequitable. Only in a few instances have revenues from stool community lands been actually used to the upkeep and defence of stool, the celebration of festivals, and the development of projects like schools, electric 
poles, markets etc. In the past chiefs were seen as custodians while citizens had secure rights. Now the former behave like landlords collecting rents and sales from land for their own personal use. The excuse provided by the chiefs to avoid any obligation to share the income with members of the community is the payment of $55 \%$ to the local government (see constitutional formula for rent disbursement under OASL). They argue that the purpose of this is to channel benefits to residents of the district, if not specifically to the local owners of the communal property from which the revenue originally derived.

\section{The District Assembly}

To eliminate doubt in the minds of other entitled beneficiaries (particularly the stools) as to how the District Assembly uses its share of stool land revenue, it is suggested that the Stools and Traditional Councils should be consulted in the selection of projects. The stools could submit project proposals to the Assembly for consideration. This should be done during the budget preparation stage which may be incorporated in the Assembly's overall development plans for consideration by the Assembly. Towards this end, the District Assembly should determine an agreed percentage of total Stool land revenue to be committed to projects as identified and prioritized by the Traditional Authorities and Stools. The final decision arrived at by the Assembly with respect to projects approved "under Stool Lands Revenue" should be communicated to the Regional Office of the Office of the Administrator of Stool Lands, Regional Coordinating Council, Traditional Authorities and Stools by the end of the first quarter of every year. At the end of every financial year, the District Assembly should report on projects approved for execution and executed "under Stool Lands Revenue". Copies of such Annual Report should be made available to the Regional Office of the Administrator of Stool Lands, Regional Coordinating Council, Traditional Authorities and Stools. Such projects should be labeled "Stool Land Revenue (SLR) Project"
Lastly, there is the need for the Assembly to spread its Stool Land Revenue projects across the length and breadth of the Atwima Nwabiagya district for the benefit of people under its jurisdiction. This recommendation stems from the fact that, currently most of the projects undertaken by the Assembly are located in the district capital.

Office of the Administrator of Stool Lands (OASL)

For the regional Office of the OASL to be effective and efficient in the performance of its constitutional and legal duties it is important that attention be paid first to logistical problems;

1. The need for the Office to be resourced in terms of personnel, finance and more importantly logistics.

2. The need to retain a portion, say $20 \%$ of the IGF to cater for certain basic logistics like motor bikes and computers for its work.

3. Government funding or yearly subvention meant for the Office should also be released on time to ensure proper planning and budgeting by the Office.

4. Besides, conditions of service would have to be improved to attract and retain professionally qualified personnel to work with the Office.

It is important to mention that a formal or legal mechanism be put in place for the strict monitoring of disbursed stool land revenue by the Office. This would empower the Office to be effective in the area of prosecuting defaulters and then ensuring that beneficiaries, especially the District Assemblies fully utilize stool land revenue for developmental projects that would benefit people of the study area. In this respect, Act 481 would have to be amended and a supporting Legislative Instrument enacted to facilitate the operations of the Office to ensure the judicious use of stool land revenue by beneficiaries for people in the study area.

Thirdly, to solve the problem of boundaries and for that matter unidentifiable land owners that 
invariably affect revenue collection, it is recommended that the current demarcation exercise by the Land Administration Project be expedited. In view of the immense importance of boundary demarcation, District Assemblies and Stools should contribute to the cost of the exercise.

\section{CONCLUSION}

This study examined land revenue management. The study indicated that these problems highlighted have long been associated with land management in the non-state sector and various attempts have been made to address them. The fact that the non-state sector has about $80 \%$ of the total lands of Ghana indicate their importance and for that matter there is the need to devise an effective mechanism to effectively utilize the proceeds coming to that sector. Based on the information gathered certain recommendations including improvement in records management, legal mechanism for monitoring use of stool revenue, stool land boundary demarcation have been made to serve as possible guidelines for the effective management of stool land revenue in Ghana as whole. Its time the nation paid serious attention to stool land revenue.

\section{Endnotes}

1. Local Government Act which establishes the District Assembly

2. At the time of writing this work the exchange rate between the Ghana cedi and US dollar was $1 \mathrm{USD}=0.95$ Ghana cedi

3. ${ }^{3}$ Drink money is a token payment to a traditional head in lieu of a visit. In recent times it could be huge sums of money, sometimes equivalent to the open market value of the land.

4. Junior secondary schools now called junior high schools

5. The title of the paramount chief of the Asante ethnic group

\section{REFERENCES}

Agbosu, L. K. (2005). The Legal Basis for the Management of Customary Lands Revenue Challenges and Future Prospects (Unpublished).

Botchie, G. (2000). Local Strategic Planning and Sustainable Rural Livelihoods- Rural District Planning Ghana. A Case Study" (ISSER) Legon, Accra. A report to the UK Department for International Development (IIED)

Ewusi, K. (1978). Planning for the Neglected Rural Poor in Ghana, Institute of Statistical, Social and Economic Research (ISSSER) University of Ghana, Legon. New Times Corporation, Accra.

Government of Ghana (2003). Emerging Land Tenure Issues. Ministry of Lands and Forestry, Accra.

Government of Ghana, Human Development Report (1997). Ghana Publishing Corporation, Accra.

Kasanga, R.K. (1988). Land Tenure and the Development Dialogue. The Myth Concerning Communal Landholding in Ghana. Granta Editions Ltd.Cambidge, UK.

Kasanga, K. and Kotey, N. A. (2001). Land Management in Ghana: Building on Tradition and Modernity. International Institute for Environment and Development (IIED), London. Russell Press, Nottingham, UK.

Naylor, R. (1999). The Oxfam Country Profile of Ghana (Unpublished). 